\title{
Innovation in the Malaysian Furniture Industry: Drivers and Challenges
}

\author{
Jegatheswaran Ratnasingam, ${ }^{\mathrm{a}, *}$ Chin Khoon Ark, ${ }^{\mathrm{a}}$ Hazirah Ab Latib, ${ }^{\mathrm{a}}$ \\ Hasshviny Subramaniam, ${ }^{a}$ and Albert Khoo ${ }^{b}$
}

\begin{abstract}
The Malaysian furniture industry is the country's fastest growing subsector within the wood-based industry, and its socio-economic importance cannot be taken lightly. The industry is driven primarily by comparative advantages derived from low cost factor inputs, which has eroded in recent years due to escalating production cost. Further, the increasing competition from other cheaper producing nations, particularly China and Vietnam, is also putting a damper on the future competitiveness of the industry in Malaysia. To remain competitive, the Malaysian furniture industry must transform and advance the value-chain through innovation and value-addition. Although the government has played a pivotal role in providing a broad policy framework to support value-adding and innovative activities, success has been limited. This study evaluated the extent of innovation and its sources in the Malaysian furniture industry through an internet-based survey. The results indicated that external sources of innovation were more important than internal sources. The factor analysis showed that external inputs, market demand, and in-house research and development were the most important drivers of the innovation in the Malaysian furniture industry. Therefore, the furniture industry in Malaysia will require policy support to enhance its inherent capability for innovation in the long-term.
\end{abstract}

Keywords: Design; Furniture; Innovation; Market; Technology; Value-addition

Contact information: a: Universiti Putra Malaysia, Faculty of Forestry, 43400 UPM, Serdang, Selangor, Malaysia; b: Lot 19A, $19^{\text {th }}$ Floor, Menara PGRM, 8, Jalan Pudu Ulu, Cheras, 56100 Kuala Lumpur, Malaysia; *Corresponding authors:jegaratnasingam@yahoo.com

\section{INTRODUCTION}

Blessed with a rich forest resource and an ample workforce, the furniture industry in Malaysia has grown from humble cottage-based beginnings to a multi-billion-dollar, export-oriented industry over the last three decades. The emergence of regional low-cost furniture producers, especially China and Vietnam, has put the Malaysian furniture industry under growing competitive pressure (Ratnasingam 2012). Being a large exportoriented furniture manufacturer, Malaysia exports $85 \%$ of its annual production volume to more than 160 countries throughout the world. Ranked the $9^{\text {th }}$ largest furniture exporter in the world in 2017, with an export value of nearly 2.1 billion USD, Malaysia's main furniture export destinations are the USA, Japan, and Australia. Despite these achievements, the furniture manufacturing industry is regarded as a low-wage economy, with diminishing profitability attributed to lack of innovation and value-addition (Ratnasingam 2016, 2017). However, studies on innovation trends in the Malaysian furniture industry is limited, and the prevailing information gap on this subject remains unfilled. Therefore, this paper aims to analyse the extent of innovation among furniture 
companies in Malaysia, with an in-depth analysis of the drivers of innovation. The study also evaluates the challenges faced by the furniture industry as it attempts to move up the value-chain in order to remain competitive.

\section{The Malaysian Furniture Industry}

The Malaysian furniture industry is currently an important socioeconomic sector in the country, contributing in excess of USD 2 billion annually in foreign exchange, while providing employment to almost 90,000 workers (Ratnasingam 2016). When the domestic market for furniture is taken into consideration, the net volume of furniture produced within the country exceeds the USD 3.2 billion per annum. Hence, the furniture industry has earned the accolade as being the fastest growing sub-sector within the overall Malaysian wood industry.

Among the furniture types exported are kitchen furniture, bedroom furniture, upholstered furniture, and office furniture, of which over 80 percent are made from rubberwood (Hevea brasiliensis). Rubberwood is a light coloured, medium hardwood, also known as 'Malaysian oak'. The export of garden or outdoor furniture from the more durable tropical hardwood, specifically Meranti (Shorea sp.) and Nyatoh (Palaquium sp.), is mainly for the European market. In addition to these traditional markets, Malaysian furniture has gained access to markets in New Zealand, South America, Middle East, Africa, and Russia. Malaysia is also presently a major supplier of office furniture to the Middle East.

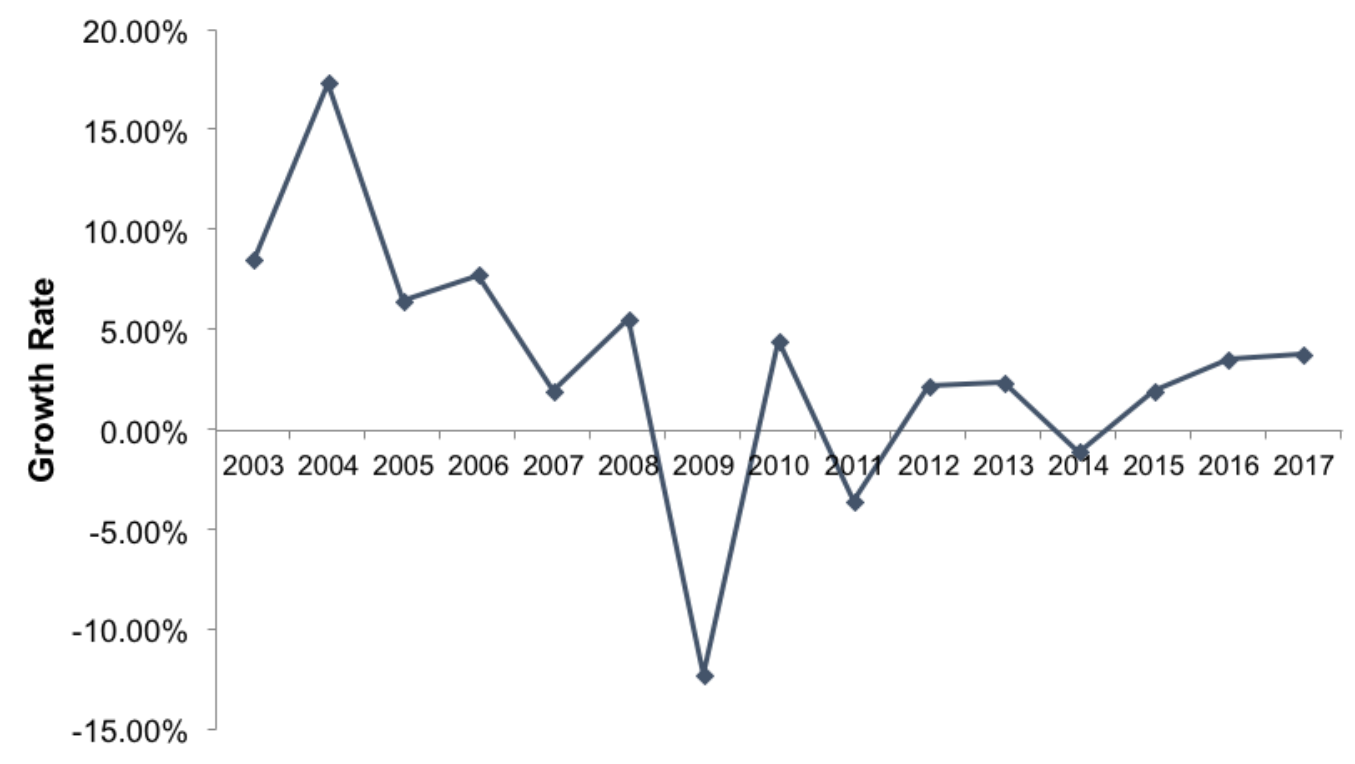

Fig. 1. Annual growth rate of furniture exports in Malaysia, 2003-2017 (Source: Department of Statistics, Malaysia).

Wooden furniture has emerged as the largest sub-sector within the overall furniture industry, accounting for almost a third of the total export receipts of the country. The furniture industry has been earmarked as a target industry under the series of Industrial Master Plans (IMPs) and the National Timber Industry Plan (NATIP) to achieve an export target of 2.5 billion USD by 2020, and has been accorded special incentives to boost export growth (Bhattacharya 2002; Ratnasingam and Ioras 2003; Asid 2010). 


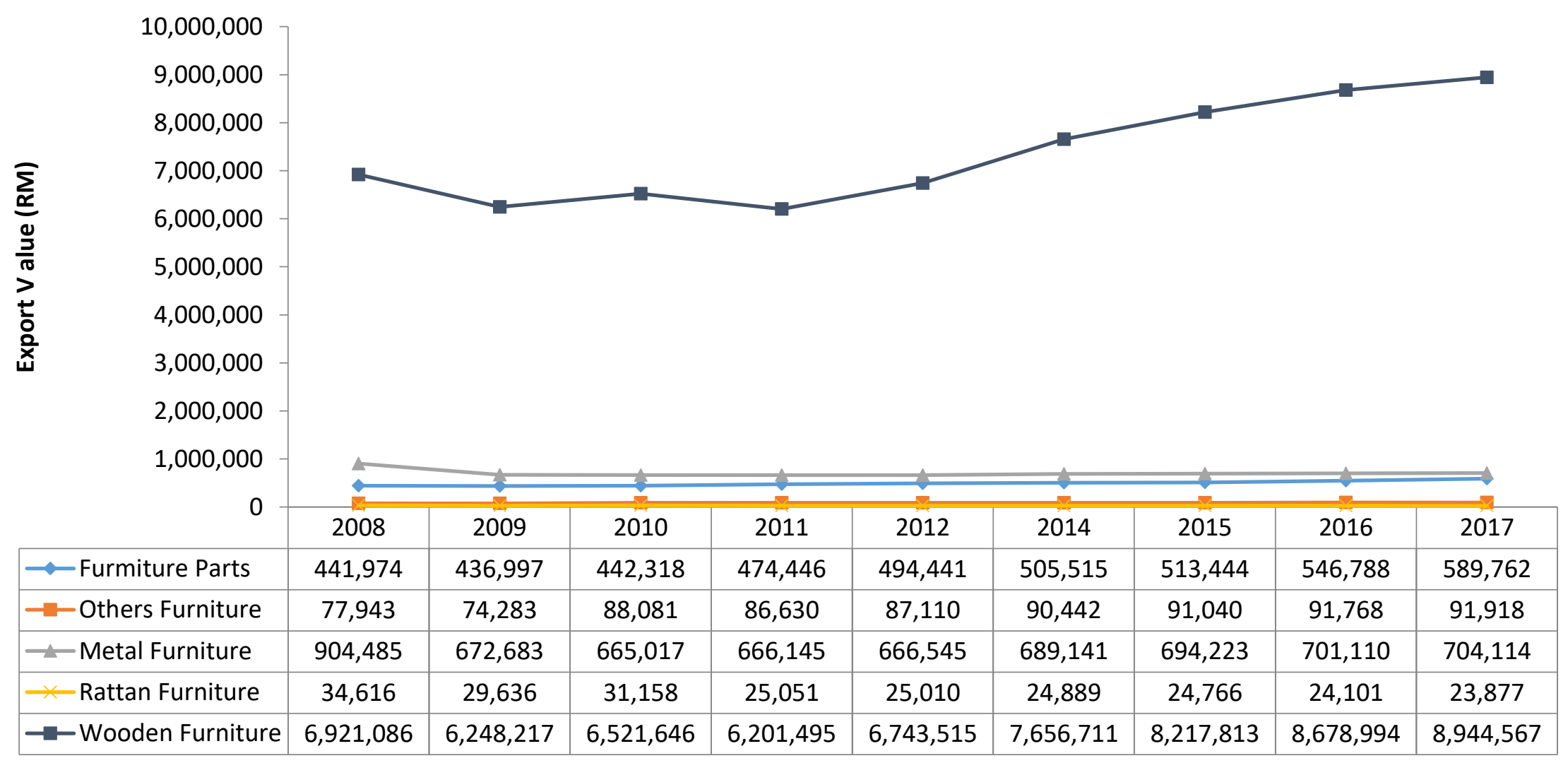

Fig. 2. Type of furniture export from Malaysia, 2008-2017. Values are shown in RM Million. (Source: Department of Statistics, Malaysia). 


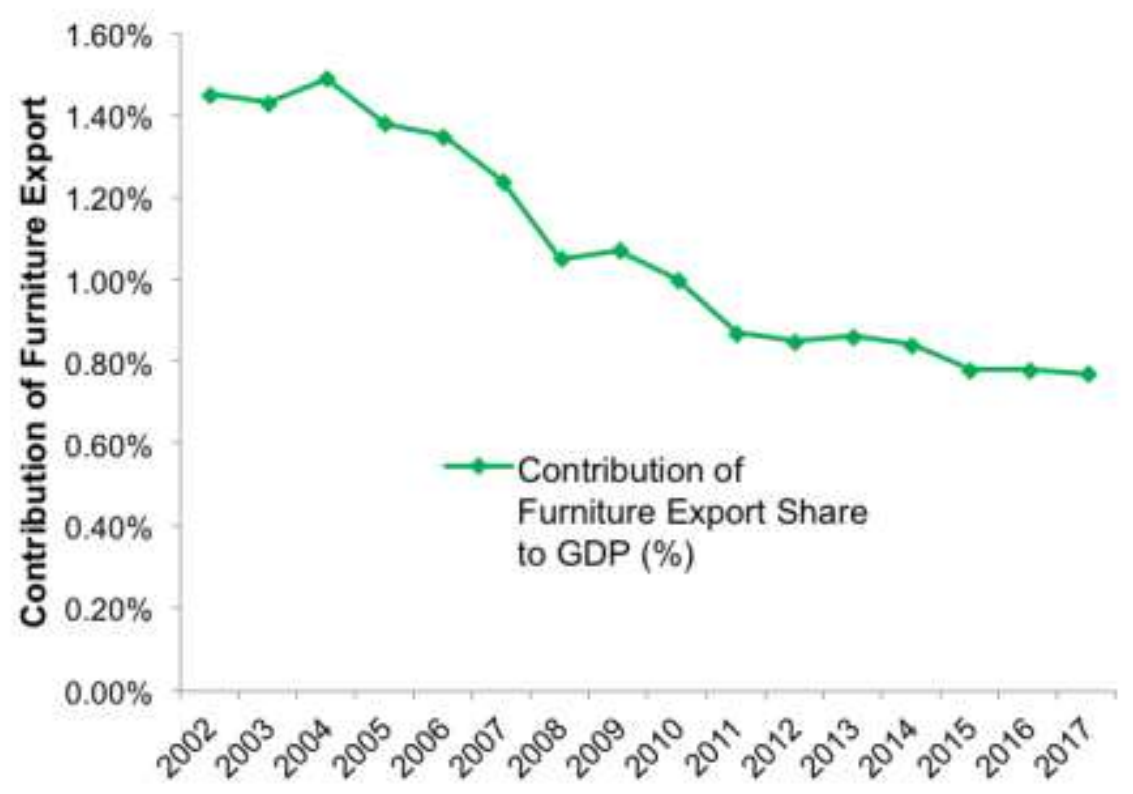

Fig. 3. Contribution of furniture export value share to gross domestic product (GDP) of Malaysia (Source: Department of Statistics, Malaysia).

Against the rapidly globalizing furniture trade however, the Malaysian furniture industry is beginning to show signs of slower growth compared to its earlier days (Fig. 1). This trend is evident from the reducing rate of export growth as well as the furniture sector's declining contribution towards the national gross domestic product, GDP (Fig. 2 and Fig. 3).

The government, in realizing the need for greater value-addition and innovation activities in the furniture industry, has formulated a blue-print for innovation activities as stipulated in the $2^{\text {nd }}$ Industrial Master Plan (1996-2005) and the on-going $3^{\text {rd }}$ Industrial Master Plan (2006-2020). However, the extent of value-addition and innovation within the industry has been somewhat limited (Ng and Thiruchelvam 2012). Previous studies by Ratnasingam and Ioras (2009) have highlighted several challenges and impediments that hinder value-addition growth in the furniture industry, and the important factors are identified below.

\section{Declining Low-Cost Factor Inputs}

The diminishing supply of rubberwood (Hevea brasiliensis) and the increasing labor-cost, even among foreign workers, has seriously impacted the low-cost stature of the furniture manufacturing industry in Malaysia (Ratnasingam et al. 2007). As shown in a report by Lim et al. (2016), an increasing proportion of hardwoods from North America and Oceania are being imported into the country to off-set the short supply in rubberwood, especially among furniture manufacturers. In 2016, a total of $417,000 \mathrm{~m}^{3}$ of wood materials were imported from other countries to cater to the growing demand for wood materials from the furniture industry (Ratnasingam 2017). From a workforce perspective, around $62 \%$ of the workers engaged in the furniture industry in Malaysia are foreign-contract workers who adversely affect skills retention and innovative capacities within the industry (Ratnasingam and Ioras 2009). Against the background of declining comparative advantage, the furniture industry needs to boost its competitive advantage in order to 
remain globally competitive, by moving up along the value-chain through innovation and value-added manufacturing.

\section{Legality and Environment Certification}

The complex process and high implementation cost have often been cited as the main reasons that deter many furniture producing nations from adopting forest resources certification. The direct cost of forest management certification can add up to $\$ 1.50 / \mathrm{m}^{3}$, depending on the size of the certification unit and local operating conditions, while the chain-of-custody (CoC) can chalk up another $\$ 1.20 / \mathrm{m}^{3}$ (Ratnasingam et al. 2008a,b). Inevitably, it is no surprise that the adoption of forest certification and $\mathrm{CoC}$ has been relatively slow within the Malaysian forest industries, as the green premium price tag offered for certified wood products appears to be much lower than anticipated in the global market place. Further, most furniture manufacturers are also reluctant to make the high initial investment to obtain the certification, as it is perceived that the economic returns on such investment is marginal.

Furthermore, the non-binding special privileges enjoyed by the states of Sarawak and Sabah in East Malaysia, as stipulated in the Federal Constitution also hinders the efforts by the Malaysian Timber Certification Council (MTCC) to implement the standardized MyTLAS (Malaysian Timber Legality Assurance System) throughout the country. Since forestry is a state matter under the Federal Constitution, the respective state has the liberty to either adopt or discard any related federal initiatives to suit their respective needs. In this context, the forest certification efforts in Malaysia have been negatively impacted by the reluctance of the East Malaysian states to comply with the federal government's initiatives (Ratnasingam 2012).

Consequently, $\mathrm{CoC}$ adoption among furniture manufacturers in Malaysia is relatively low. Therefore, the promotion of Malaysian furniture as being green and ecofriendly is sluggish and cannot be translated into a potent marketing tool to enhance product value (Ratnasingam 2017).

\section{Inconsistencies in Policy Directions}

The Malaysian wood-based industry, especially the furniture sector, comes under the purview of several Ministries, such as the Ministry of International Trade and Industry (MITI), the Ministry of Plantation and Commodities (MPIC), and the Ministry of Human Resources (MOHR). Unfortunately, the policy directions of these ministries often contradict each other, which has affected productivity and overall industrial competitiveness. For instance, the employment of foreign workers for the industry is often subjected to increasing regulatory requirements, to an extent that workforce shortage is a prevailing challenge. As local workers are reluctant to seek employment in the furniture industry due to the prevailing low-wages and the 3D-syndrome (i.e. dirty, dangerous, and demeaning) associated with the industry, the workforce gap must be filled by foreigncontract workers if industrial activity is not to be adversely affected (Reinhardt 2000; Ratnasingam et al. 2012). Other issues related to inconsistent raw materials supply and export facilitation have also been influenced by overlapping policy directions, which retards the capacity of the furniture manufacturing industry in the country (Ratnasingam 2017).

Another point of concern is the implementation of a series of Industrial Master Plans (IMPs) since the mid-1980s, which led to an aggressive engagement of many public research and development (R\&D) agencies with the furniture industry. Unfortunately, the 
outcomes have been rather poor, as the uncoordinated R\&D activities, which most often involved "reinventing the wheel", had minimal impact on the industry (Ahmad 2003), and the desired up-scaling of the industry was not realized. Despite the availability of substantial research grants and extensive research facilities, the lack of network between academia and industry, and the prevailing sub-standard human capital, especially among furniture designers and prototype-makers, has stifled innovation and creativity within the industry (Dell'Era and Verganti 2007). Therefore, a concerted and coordinated policy framework is a necessity if the furniture industry in the country is to boost its innovative capacity and move along further the value-chain (i.e. the process or activities by which a company adds value to an article, including production, marketing, and the provision of after-sales service).

\section{Innovation and Innovation Activities}

Innovation is defined as the implementation of a new or significantly improved product (good or service), or process, a new marketing method, or a new organizational method in business practices, workplace organization, or external relations. The minimum requirement for an innovation is that the product, process, marketing method or organizational method must be new (or significantly improved) to the firm. Innovation activities are all scientific, technological, organizational, financial, and commercial steps that actually, or are intended to, lead to the implementation of innovations. Some innovation activities are themselves innovative, whereas others are not novel activities but are necessary for the implementation of innovations. Innovation activities also include $\mathrm{R} \& \mathrm{D}$ that is not directly related to the development of a specific innovation. Generally, four types of innovations are distinguished: product innovations, process innovations, marketing innovations, and organizational innovations, but in the case of LMTs, product, process and marketing innovations are the most common (Anon. 2005).

The work of Joseph Schumpeter has greatly influenced theories of innovation (Anon. 2005; Ratnasingam 2016). He argued that economic development is driven by innovation through a dynamic process in which new technologies replace the old, a process he labelled "creative destruction" (Anon. 2005). Through innovation, new knowledge is created and diffused, expanding the economy's potential to develop new products and more productive methods of operation. Such improvements depend not only on technological knowledge, but also on other forms of knowledge that are used to develop product, process, marketing, and organizational innovations. Specific types of innovation can differ greatly in their impact on firm performance and on economic change. Innovation is often associated with uncertainty over the outcome of innovation activities, and is characterized by its: (1) need for investment, (2) subject to spillovers, and (3) involvement with the utilization of new knowledge or a new use or combination of existing knowledge.

In essence, innovation aims at improving a firm's performance by gaining a competitive advantage (or simply maintaining competitiveness) by shifting the demand curve of the firm's products. However, low and medium technology (LMTs) industries, such as furniture manufacturing, are generally characterized by incremental innovation and adoption. Under such circumstances, innovation activities are often focused on production efficiency, product differentiation, and marketing. Nevertheless, finance can be a determining factor for innovation in SMEs, which often lack internal funds to conduct innovation projects and have much more difficulty obtaining external funding than larger firms. This is particularly relevant to the furniture industry, as SMEs predominate the industry to a large extent (Anon. 2005). 


\section{Weak Value Addition Trend}

The furniture industry in Malaysia is a matured industry, as it shows favorable development despite the issues and challenges confronted by the industry ( $\mathrm{Ng}$ and Thiruchelvam 2012); however, its operational strategies will need to be revamped if it is to stave off the competitive pressure from other furniture producing nations in the region. The point of concern is the relatively low innovation status within the industry, and as suggested in the study by Sales (2001), the success of Malaysian furniture can be attributed to its comparative advantage (i.e., competitive pricing) derived from low-cost factor inputs. Unfortunately, this comparative advantage is quickly eroding, and the furniture industry needs to gain additional competitive advantages in order to remain viable (Ratnasingam 2017).

The argument that the Malaysian furniture industry is steadily growing may be a fallacy, as growth is driven primarily by incremental inputs and not through productivity gains (Ratnasingam 2017). The declining value-addition growth is evident in Table 1, which reflects the deteriorating value-addition intensity amidst the increasing factor input cost. Value-addition is defined as the amount by which the value of an article is increased at each stage of its production, exclusive of initial costs. In this context, the comparativeadvantage nature of the Malaysian furniture industry, based on abundant resources, is apparent. The industry did not rely heavily on innovation, leading to a reduction in valueaddition intensity (Ratnasingam 2002 and 2017). Therefore, without an increase in innovation and creativity within the Malaysian furniture industry, its growth may stagnate. The increasing cost of factor inputs usually offset through economies of scale; however, this will prove unsustainable in the long-run as the supply of competitive factor inputs also diminishes.

Table 1. Value Addition Trend

\begin{tabular}{|c|c|c|}
\hline Year & Value Addition Growth* $(\%)$ & Value Addition Intensity* $(\%)$ \\
\hline 2000 & $33.50 \%$ & $31.77 \%$ \\
\hline 2001 & $-8.20 \%$ & $31.48 \%$ \\
\hline 2002 & $-4.60 \%$ & $25.08 \%$ \\
\hline 2003 & $-2.40 \%$ & $24.35 \%$ \\
\hline 2004 & $14.80 \%$ & $23.08 \%$ \\
\hline 2005 & $16.00 \%$ & $23.56 \%$ \\
\hline 2006 & $6.10 \%$ & $23.48 \%$ \\
\hline 2007 & $3.80 \%$ & $22.40 \%$ \\
\hline 2008 & $7.20 \%$ & $23.33 \%$ \\
\hline 2009 & $4.17 \%$ & $25.48 \%$ \\
\hline 2010 & $1.70 \%$ & $28.00 \%$ \\
\hline 2011 & $-5.67 \%$ & $27.01 \%$ \\
\hline 2012 & $-51.67 \%$ & $26.35 \%$ \\
\hline 2013 & $-32.14 \%$ & $24.14 \%$ \\
\hline 2014 & $-14.09 \%$ & $23.89 \%$ \\
\hline 2015 & $-6.14 \%$ & $22.15 \%$ \\
\hline 2016 & $-5.78 \%$ & $22.04 \%$ \\
\hline *Source: Ratnasingam $(2017)$ & \\
\hline
\end{tabular}




\section{EXPERIMENTAL}

\section{Target Respondents}

The study was carried out through an internet-based questionnaire survey sent to 650 randomly selected furniture manufacturers throughout Malaysia, who were registered with the Malaysian Timber Industry Board (MTIB).

\section{Questionnaire Design}

The questionnaire used in this study had 4 parts, and it was designed and prepared after discussions with industry experts, academics, consultants, designers, and furniture manufacturers, who have been involved in innovation and creative activities within the industry. When creating the questionnaire, the researchers also referred to the OSLO Manual on Innovation (Anon. 2005) and several previous studies by Lee and Lee (2007). The framework for the questionnaire design and the questions included were as suggested by the OSLO Manual and was also approved by the panels of experts consulted.

The first part of the questionnaire compiled respondent profile data for the furniture manufacturers, such as company name, year of establishment, company size, number of workers, average annual sales turnover, main market, main products manufactured, availability of in-house research and development personnel, design capacity, and prototype-making specialist.

The second part of the questionnaire required the respondents to rank the subsectors within the country's wood products industry by their perception of the current status of innovation. The respondents were also required to provide supporting statements to justify their innovative perception and ranking of the various sub-sectors.

The third part of the questionnaire evaluated the drivers of innovation and creativity within the furniture manufacturer's company. A total of 16 factors were categorized into two broad groups, i.e. internal sources, which includes design, in-house $R \& D$, management, human capital, technology, raw materials, and processing methods. The other category of external sources included factors such as government policy, universities/research organization, consultants, competitors, linkages and industrial network, green markets and products, suppliers, market demand, and customers. These factors were ranked by their importance towards innovation and creativity in the company, which allowed the identification of the main sources of innovation among furniture manufacturers.

The fourth part of this survey required the respondents to rate the factors from part 3 of the survey by their level of importance. The ranking was based on Likert's five-point rating scale, from 1 (strongly unimportant) to 5 (strongly important). These responses were then used to carry out a factor analysis to determine which factors had a significant influence on the extent of innovation in the Malaysian furniture industry.

The fifth part of the survey required the respondents to identify their important challenges to the future sustainability of the furniture manufacturing industry in the country.

\section{Data Collection}

The questionnaire was initially pre-tested among 20 furniture manufacturers around the Klang-Valley in Malaysia, and after obtaining their responses and comments the questionnaire was modified accordingly to ensure clarity and ease of implementation. The revised questionnaire was then converted into an internet-based questionnaire using the 
survey-monkey platform, and linked to an email, which was sent to the selected respondents, based on the MTIB's membership list. At the end of the 60-day period, 79\% or 514 of the target respondents had answered the questionnaire.

\section{Data Analysis}

The data from the questionnaires were compiled and tabulated using Microsoft Excel to facilitate analysis. The analysis of data was conducted using the Statistical Package for the Social Sciences (SPSS; IBM, USA), to assess the extent of innovation. The main factors of innovation in the furniture industry were identified through the rank analysis of the various factors. The next part of the statistical analysis applied factor analysis to the 16 factors of innovation, to simplify the data into smaller groups of several factors that determined the extent on driving innovation, as suggested in the paper by Ratnasingam et al. (2007).

\section{RESULTS AND DISCUSSION}

\section{Company Profile}

Based on the 514 respondents, $85.30 \%$ of the companies were active in export sales (i.e., more than $70 \%$ of their total sales were exported), while the remaining $14.70 \%$ of the respondents were active in the domestic market. The manufacturing strategies used in these companies were Original Equipment Manufacturing (OEM), Original Design Manufacturing (ODM), and mixed manufacturing strategy, with 64.29\%, 13.27\%, and $22.44 \%$ of companies using these methods, respectively (Fig. 4). In this survey, there was no company that uses the Original Brand Manufacturing (OBM) strategy in their business. Hence, the results from this survey suggest that the furniture industry in Malaysia is very much in the OEM strategy, with the mixed strategy (OEM \& ODM) being the second most common employed by manufacturers.

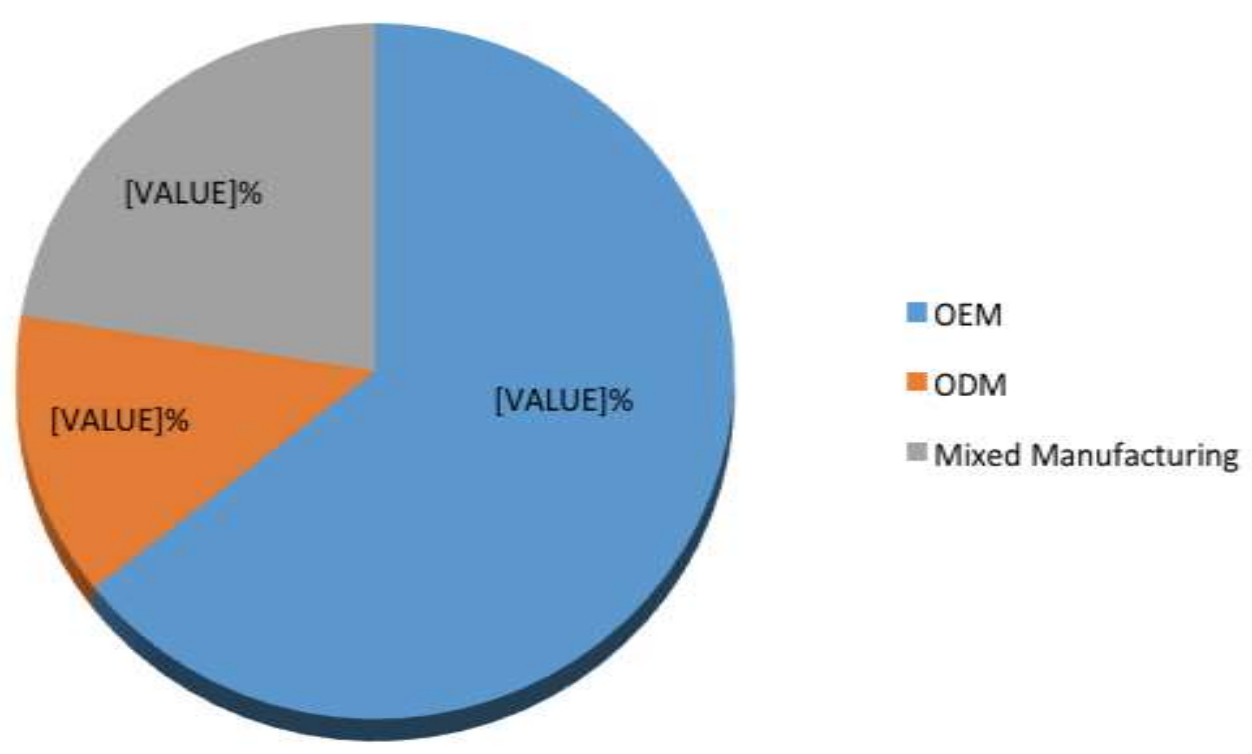

Fig. 4. Manufacturing strategy used in the furniture industry 
The results also support the notion that within the OEM manufacturing strategy, manufacturers of furniture were likely to gain an advantage through raw materials substitution, rather than through process alteration, technology adoption, or even design creation. Such a finding clearly underlines the importance of cost-centric manufacturing practices, which is geared towards competitiveness gained through pricing rather than innovation and creativity (Ratnasingam 2016).

Another important observation from the survey is the fact that generally SMEs are less active in R\&D activities compared to their larger counter-parts, which also explains why the furniture sector appears to be operating within the realms of the OEM strategy. In fact, as design innovations are imitable, there is general reluctance among furniture manufacturers to embark on developing new designs, as they faced difficulty in protecting their design rights (Ratnasingam 2016). The SMEs in the furniture sector are generally limited by their financial resources to employ designers, let alone embark on research activities to boost their innovation, similar to the report in the OSLO Manual (Anon. 2005).

\section{Status of Innovation in the Wood Products Industry}

Based on the survey, $84.92 \%$ of companies strongly agree that innovation is important for business growth. However, $61.22 \%$ of companies disagreed that wood-based industry, in general, is an innovative manufacturing industry in Malaysia. Figure 5 shows the ranking of the innovative sub-sectors within the wood-based industry, which has most of the innovative activities.

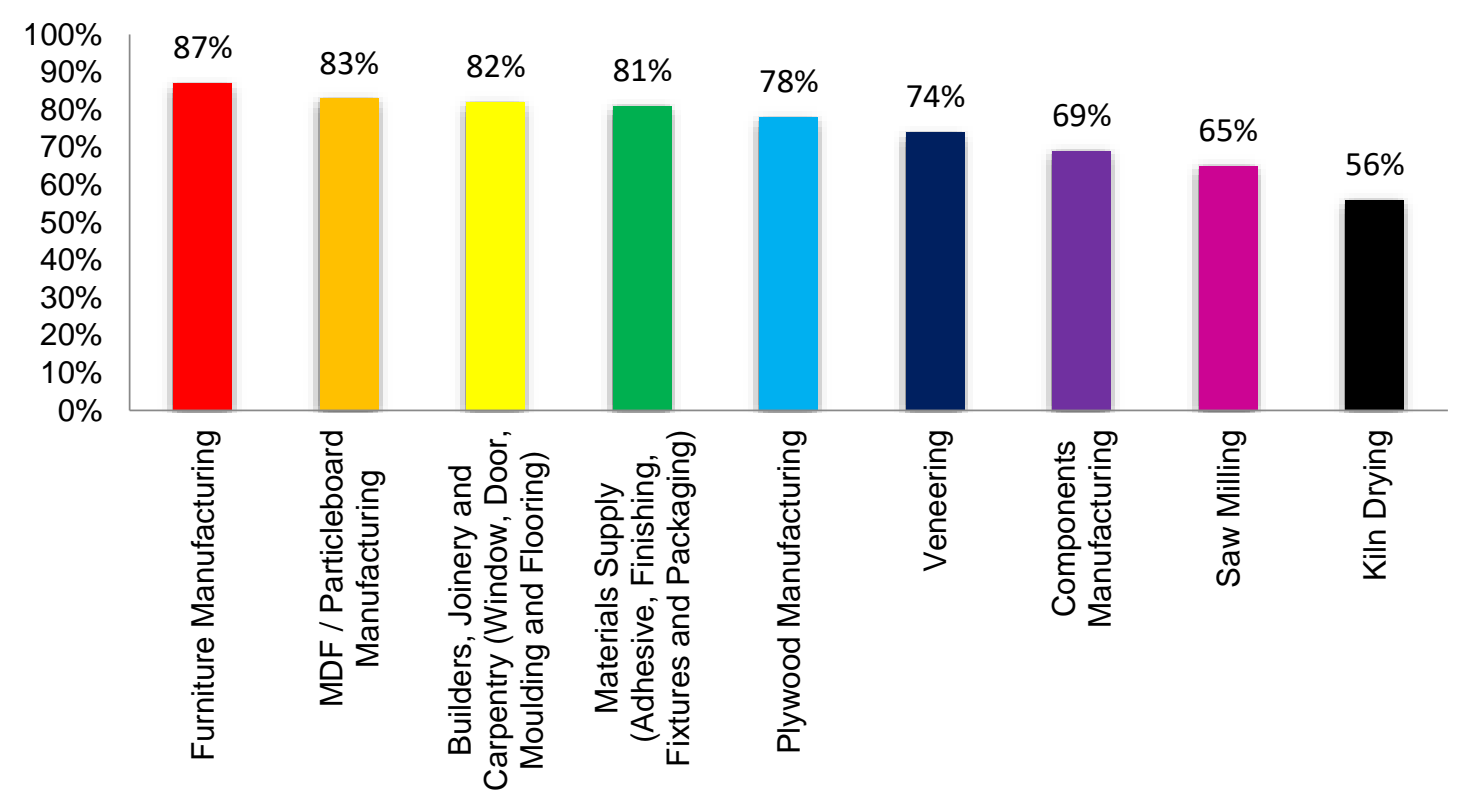

Fig. 5. Innovative sector in the Wood-Based Industry in Malaysia Perception

Accordingly, the respondents ranked furniture manufacturing as the most innovative sub-sector within the wood-based industry $(87 \%)$, followed by medium density particleboard (MDF) and particleboard manufacturing (83\%), and builders, joinery, and carpentry (BJC) which consists of window, door, molding, and flooring was ranked next at $82 \%$. The fourth most innovative sub-sector according to the respondents was the materials supply (81\%), which consists of adhesive, finishing, fixture, and packaging. 
These ranking were supported by previous research by Ratnasingam (2017), who found furniture to have the highest value-adding ratio among all the sub-sectors within the wood-based industry. Ratnasingam (2017) conquered that furniture manufacturing had a 6.5 times greater value-added ratio than its closest rival, the MDF and particleboard subsector, which is highly automated and capital intensive. The furniture sector, through its design, raw materials, and process variations, achieves a high level of innovation and creativity, which leads to high price-point per unit volume of material input (Ratnasingam 2016).

\section{Sources of Innovation in the Wood Products Industry}

From the survey, it was apparent that external sources were more important in driving innovation in the furniture industry in Malaysia than internal sources. This finding is similar to the report by Natkuncaran and Bennett (2009), who suggested that the sources of innovations in the furniture sector derived primarily from external sources, especially from suppliers and customers (Fig. 6). This finding is also in line with the report by Ratnasingam (2017), who indicated that in-house research and development activities are limited, especially among furniture manufacturers.

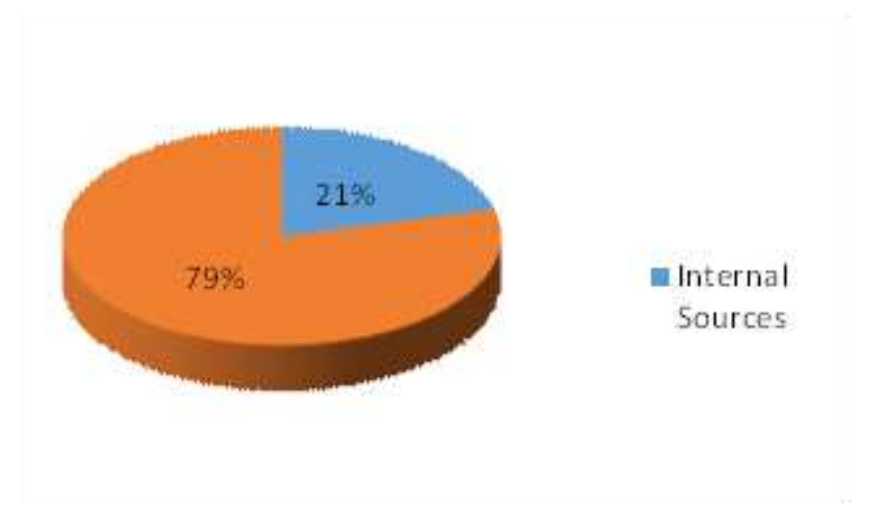

Fig. 6. Sources of innovation in the furniture industry

When comparing the importance of internal innovation factors, the respondents' ranked processing method first ( $92 \%)$, followed by raw material second (88\%), technology in third position (76\%), and human capital in fourth at 70\% (Fig. 7).

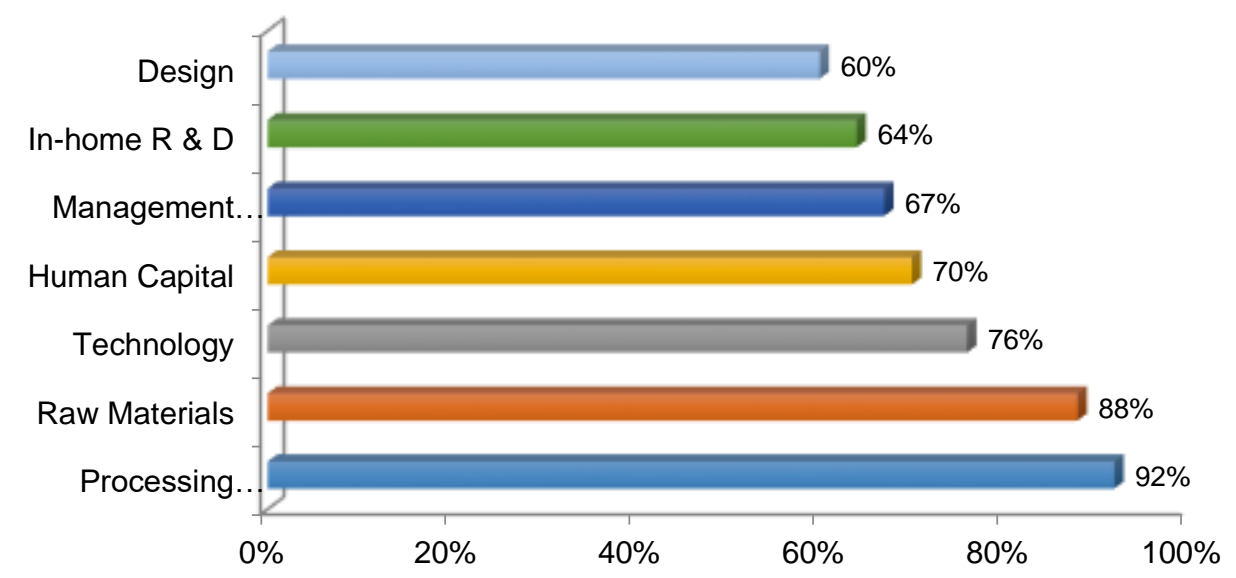

Fig. 7. Internal factors of innovation 
In contrast, in ranking external innovation factors, customers were ranked first at $92 \%$, followed by market demand at $90 \%$, followed by suppliers at $88 \%$. The survey revealed that universities, research institutes, and government polices gained the lowest importance as sources of innovation, clearly implying that public R\&D activities have not gained traction and acceptance among the furniture manufacturers in the country (Fig. 8).

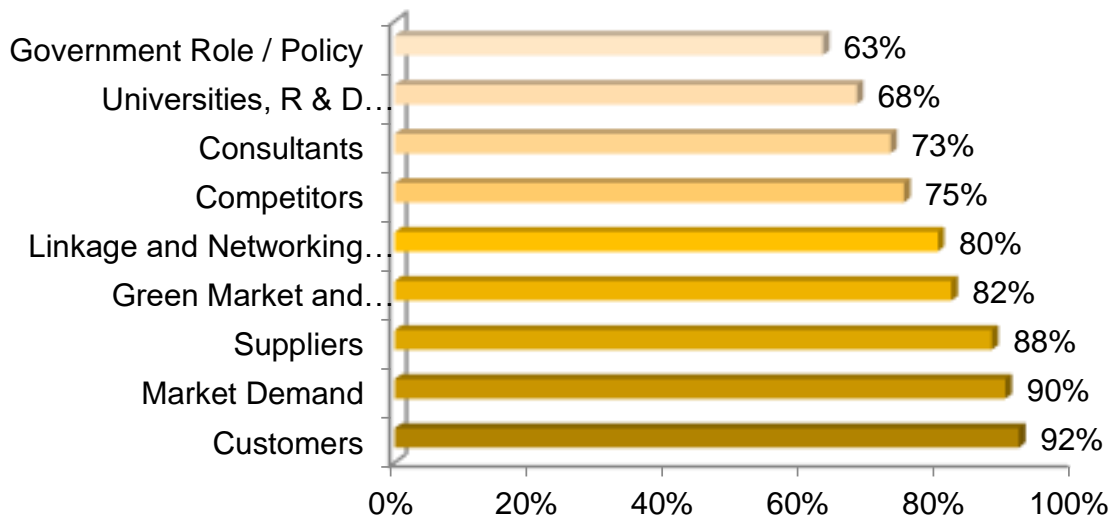

Fig. 8. External factors of innovation

Table 2. Four Factor Solutions from the Factor Analysis of Innovation Drivers in the Furniture Industry

\begin{tabular}{|c|c|c|c|c|c|}
\hline No. & Attributes & $\begin{array}{l}\text { Group } 1 \\
\text { In-House } \\
\text { R\&D }\end{array}$ & $\begin{array}{l}\text { Group } 2 \\
\text { External } \\
\text { Inputs }\end{array}$ & $\begin{array}{l}\text { Group } 3 \\
\text { Market } \\
\text { Demand }\end{array}$ & $\begin{array}{c}\text { Group } 4 \\
\text { Institutional } \\
\text { Inputs }\end{array}$ \\
\hline 1. & Design & 0.718 & 0.166 & 0.337 & -0.108 \\
\hline 2. & In-House R\&D & 0.813 & 0.180 & -0.216 & 0.410 \\
\hline 3. & Management & 0.514 & -0.048 & -0.191 & 0.426 \\
\hline 4. & Human Capital & 0.617 & 0.411 & 0.388 & -0.118 \\
\hline 5. & Technology & 0.219 & 0.769 & 0.311 & -0.129 \\
\hline 6. & Raw Materials & 0.544 & 0.399 & 0.416 & 0.316 \\
\hline 7. & Processing Method & 0.219 & 0.544 & 0.399 & 0.382 \\
\hline 8. & Government Policy & 0.139 & -0.121 & -0.217 & -0.513 \\
\hline 9. & Universities, R\&D Institutes & 0.218 & -0.186 & -0.198 & 0.507 \\
\hline 10. & Consultants & 0.318 & 0.644 & -0.127 & -0.037 \\
\hline 11. & Competitors & 0.218 & 0.219 & 0.599 & -0.049 \\
\hline 12. & Suppliers & 0.327 & 0.787 & 0.410 & -0.041 \\
\hline 13. & $\begin{array}{l}\text { Linkages and Industrial } \\
\text { Networking }\end{array}$ & 0.412 & 0.691 & 0.401 & 0.477 \\
\hline 14. & Green Market and Products & -0.316 & 0.159 & 0.501 & 0.481 \\
\hline 15. & Market Demand ${ }^{*}$ & 0.293 & 0.140 & 0.718 & -0.245 \\
\hline 16. & Customers* & -0.244 & 0.811 & 0.494 & -0.215 \\
\hline
\end{tabular}

Note: Market demand refers to overall market, while customers refers to specific market segment.

\section{Factor Analysis of Innovation in the Wood Products Industry}

Factor analysis is based on the assumption that all variables in the study have correlations to some degree (Ho 2006), and the degree of correlation among the variables can be examined using the Kaiser-Meyer-Olkin method. 
The analysis in this study indicated that the correlation among the variables showed an index value of 0.361, which is quite low. The Bartlett's test of the correlation matrix sphericity yielded a value of 91.88 and an associated level of significance smaller than 0.001 . Hence, the correlation matrix had a significant correlation among some of the variables, and therefore the factor analysis was appropriate for the data collected in this study.

The factor analysis grouped the 16 factors into four main groups of factors, which could be categorized as follows: (1) in-house R\&D; (2) external inputs; (3) market demand; and (4) institutional inputs. Instead of describing the many factors driving innovation individually, factor analysis resulted in the consolidation of the factors into these four distinct groups, as shown in (Table 2).

Group 1 includes factors such as design, in-house R\&D, management, human capital, and raw materials. The factors in group 2 include technology, processing method, consultant, suppliers, industrial network, and customers. Factors in the study for group 3 include competitors, green market, and market demand, while the factors in group 4 include government policy and universities/R\&D institutes. The variance accounted for $22.6 \%$, $27.8 \%, 24.8 \%$, and $18.1 \%$, respectively, of the total variance observed among the factors. The factors in group 4 were consistent, except for government policy, which suggest that the government policy could influence innovation negatively, if not consistently. Further, having only two factors with relatively low importance, group 4 can be considered as the least important factor that drives innovation and hence can be discarded.

In this context, this study revealed that the drivers of innovation within the Malaysian furniture industry can be attributed to external inputs, market demand, and inhouse R\&D, clearly emphasizing the importance of external factors in driving innovation and enhancing the ability to move along the products value-chain. This finding is similar to the previous studies by $\mathrm{Ng}$ and Thiruchelvam (2011) and Ratnasingam (2003), who found that external sources of innovation were more important in the wood products industry in Malaysia, as there appears to be a lack of indigenous design expertise and innovative capabilities.

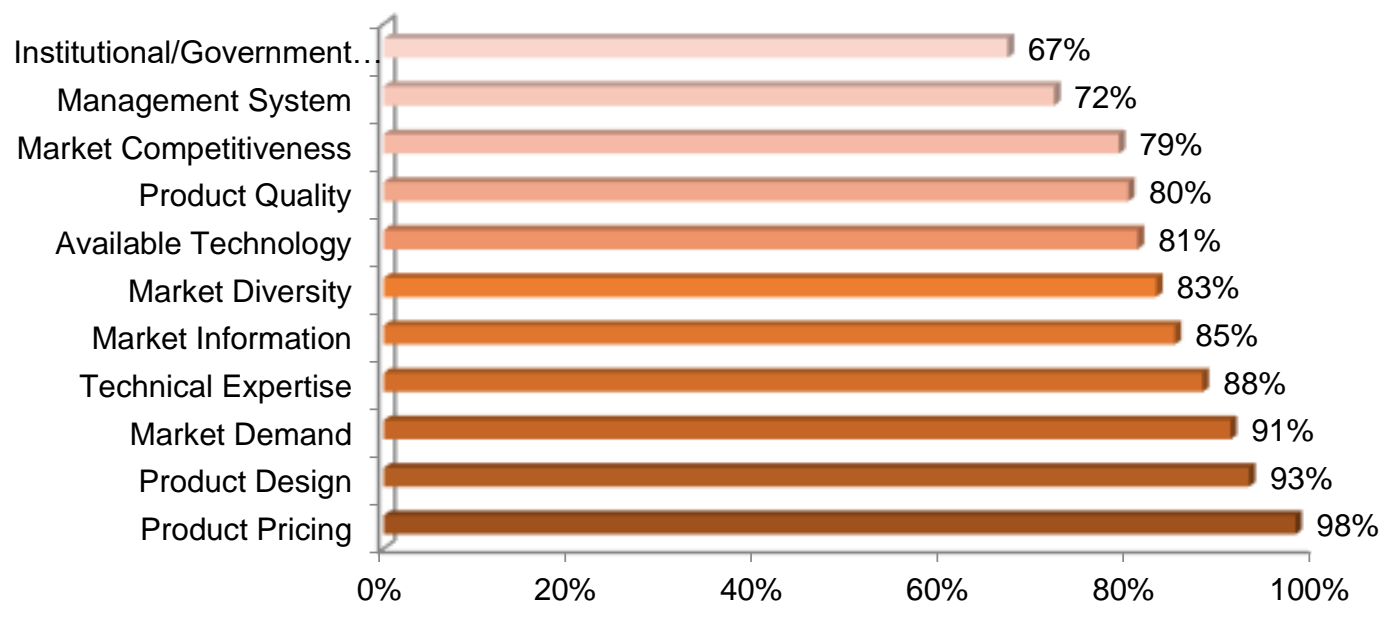

Fig. 9. Main problems affecting the furniture industry 


\section{Challenges towards Innovation in the Malaysian Furniture Industry}

The respondents reported several problems that affect innovation in the Malaysian furniture industry (Fig. 9). The surveyed companies ranked product pricing as the main problem (98\%), followed by product design (93\%), market diversification/demand (91\%), lack of technical expertise (88\%), and lack of market information (85\%).

The fact that Malaysia is regarded as a hub for contract-manufacturing (i.e., OEM strategy), price competitiveness is crucial to successful sales. Therefore, without indigenous design expertise, the extent of innovation remains limited, and when the designs are sourced externally, the product price-points are increased to a level where it becomes uncompetitive. In essence, limited innovation is the primary reason for the slow growth of innovation and creativity within the Malaysian furniture industry, despite the sub-sector being at the end of the wood products industry value-chain (Ratnasingam et al. 2013).The lack of design capability could be attributed to the lack of talented local designers, arising from the limited number of higher education training institutions involved in producing human capitals with an emphasis on furniture product design in the country (Lean 2008; Lee 2011).

Despite revealing the lack of innovation within the Malaysian furniture industry, the future sustainability of the industry will depend on the sufficient availability of raw materials and a large pool of skilled workforce at competitive cost. Without those inputs, the future of the industry may become questionable as the other regional competitors, especially China and Vietnam, increase the global market share of the furniture trade (Mahadevan 2001; Ratnasingam and Ioras 2005).

In essence, the growth and sustainability of the furniture industry in Malaysia is dependent on the industry's innovative capabilities, as it moves further along the product value-chain, while in turn increasing its socioeconomic contribution to the country. In this context, relevant government policies must be put in place to facilitate and boost innovation in the industry.

\section{CONCLUSIONS}

1. The need for innovation and creativity in the furniture industry, which is a fashion and creative product, is a necessity for sustainable growth of the industry.

2. It is apparent that innovation has been lagging in the country's wood-based sector, as industrial growth has been driven by economies of scale rather than innovation and value-addition.

3. The external factors of innovation play a more important role in driving innovation in the Malaysian furniture industry.

4. Factor analysis revealed that external inputs and market demand were more important than the in-house R\&D as the drivers of innovation in the Malaysian furniture industry.

5. The need for competitive pricing, lack of indigenous product design, and market diversification have been cited as the main challenges faced by furniture manufacturers in Malaysia, as they aspire to move further along the product value-chain. 


\section{ACKNOWLEDGEMENTS}

The authors express their gratitude to the Malaysian Furniture Council (MFC) for their support with this study. The financial support from Universiti Putra Malaysia under the PUTRA-Grant-IPS scheme, which made this study possible, is also acknowledged.

\section{REFERENCES CITED}

Ahmad, A. H. (2003). The Participation of the Wood Based Sector in the Malaysian Research and Development Grant Scheme, UPM Press, Serdang, Malaysia.

Anon (2005). OSLO MANUAL - Guidelines for Collecting and Interpreting Innovation Data, OECD Publication, Paris, France.

Asid, R. (2010). “Technical efficiency analyses of manufacturing sector in Malaysia: Evidence from the first industrial master plan," Asian Social Science 6(2), 99-107. DOI: $10.5539 / a s s . v 6 n 2 p 99$

Bhattacharya, M. (2002). "Industrial concentration and competition in Malaysian manufacturing," Applied Economics 34(17), 2127-2134. DOI: $10.1080 / 00036840210135683$

DOS (2012). "Statistics on the forest products industry," Department of Statistics Database, Putrajaya, Malaysia. (https://www.dosm.gov.my/wood/), accessed on March 3, 2018.

DOS (2014). "Statistics on the wooden furniture industry," Department of Statistic Database, Putrajaya, Malaysia. (https://www.dosm.gov.my/furniture/), accessed on March 3, 2018.

Dell'Era, C., and Verganti, R. (2007). "Strategies of innovation and imitation of product languages," Journal of Product Innovation Management 24(6), 580-599.

DOI: $10.1111 / \mathrm{j} .1540-5885.2007 .00273 . \mathrm{x}$

IMP-3 (2006). Third Industrial Master Plan (IMP) 2006-2020, Ministry of International Trade and Industry, Kuala Lumpur, Malaysia.

Lean, H. H. (2008). "The impact of foreign direct investment on the growth of the manufacturing sector in Malaysia," International Applied Economics and Management Letters 1(1), 41-45.

Lee, C. (2011). "Trade, productivity, and innovation: Firm-level evidence from Malaysian manufacturing," Journal of Asian Economics 22, 284-294. DOI: 10.1016/j.asieco.2011.05.003

Lee, C., and Lee, C. G. (2007). "SME innovation in the Malaysian manufacturing sector," Economics Bulletin 12(30), 1-12. (http://economicsbulletin.vanderbilt.edu/2007/volume12/EB-07L60001A.pdf)

Lim, C. L., Ratnasingam, J., Ramasamy, G., and Mohamed, S. (2016). The Malaysian Timber Sector: Its Raw Material and Productivity Conundrum, Universiti Putra Malaysia Press, Serdang, Malaysia. ISBN: 978-967-14353-0-4

Mahadevan, R. (2001). "Assessing the output and productivity growth of Malaysia's manufacturing sector," Journal of Asian Economics 12, 587-597.

DOI: 10.1016/S1049-0078(01)00104-X

Malaysian Furniture Promotion Council (MFPC) (2014). "Statistics on the Malaysian furniture industry export value," (http://www.mfpc.com.my), accessed on March 3, 2018. 
NATIP (2009). NATIP National Timber Industry Policy 2009-2020, National Timber Policy, Ministry of Plantation Industries and Commodities, Malaysia.

Natkuncaran, J., and Bennett, G. (2009). Creativity and Innovation - Lessons for Beginners, Pustaka Alam Press, Kuala Lumpur.

$\mathrm{Ng}$, B. K., and Thiruchelvam, K. (2011). "Sectoral innovation systems in low-tech manufacturing: Types, sources, drivers and barriers of innovation in Malaysia's wooden furniture industry," International Journal of Institutions and Economies 3(3), 549-574.

Ng, B. K., and Thiruchelvam, K. (2012). "The dynamics of innovation in Malaysia's wooden furniture industry: Innovation actors and linkages," Forest Policy and Economics 14,107-118. DOI: 10.1016/j.forpol.2011.08.011

Ratnasingam, J. (2002). The Malaysian Furniture Industry - A Pocket Guide, Irama Prasada Publications, Kuala Lumpur.

Ratnasingam, J. (2003). "A matter of design in the South East Asian wooden furniture industry," Holz als Roh-und Werkstoff 61(2), 151-154. DOI: 10.1007/s00107-0030375-8

Ratnasingam, J., and Ioras, F. (2003). "The sustainability of the Asian wooden furniture industry," Holz als Roh-und Werkstoff 61(3), 233-237. DOI: 10.1007/s00107-0030382-9

Ratnasingam, J., and Ioras, F. (2005). "The Asian furniture industry: Reality behind the statistics," Holz als Roh-und Werkstoff 63(1), 64-67. DOI: 10.1007/s00107-0040536-4

Ratnasingam, J., Ioras, F., and Macpherson, T. H. (2007). "Influence of wood species on the value of wooden furniture: The case of rubberwood," Holz als Roh-und Werkstoff 65(6), 487-489. DOI: 10.1007/s00107-007-0186-4

Ratnasingam, J., Macpherson, T. H., Ioras, F., and Abrudan, V. (2008a). "Chain of custody certification among Malaysian furniture manufacturers: Status and challenges," International Forestry Review 10(1), 23-28. DOI: 10.1505/ifor.10.1.23

Ratnasingam, J., Macpherson, T. H., and Ioras, F. (2008b). “An assessment of Malaysian wooden furniture manufacturers' readiness to embrace chain of custody (COC) certification," Holz als Roh-und Werkstoff 66(5), 339-343. DOI: 10.1007/s00107008-0255-3

Ratnasingam, J. (2008). “Internationalization of furniture design in Malaysia," Proc. IFCX International Furniture Conference \& Exhibition, 13-46.

Ratnasingam, J., and Ioras, F. (2009). "Foreign direct investment (FDI), added value and environmental-friendly practices in furniture manufacturing: The case of Malaysia and Vietnam," International Forestry Review 11(4), 464-474. DOI:

10.1505/ifor.11.4.464

Ratnasingam, J., Ioras, F., and Abrudan, I. V. (2012). "An evaluation of occupational accidents in the wooden furniture industry - A regional study in South East Asia," Safety Science 50, 1190-1195. DOI: 10.1016/j.ssci.2011.12.035

Ratnasingam, J. (2012). Innovation in the Malaysian Wood Industry - Current Status, Challenges and Future Potential, IFRG Report Singapore 23, 61.

Ratnasingam, J., Lim, T. W., Thanasegaran, G., Ioras, F., Vacalie, C., Coman, C., and Lu, W. M. (2013). "Innovations in the forest products industry: The Malaysian experience," Not Bot Horti Agrobotanici Cluj-Napoca 41(2), 601-607.

Ratnasingam, J. (2016). The Malaysian Furniture Industry: Unraveling Its Growth and Challenges to Innovation, UPM Press, Serdang, Malaysia. 
Ratnasingam, J. (2017). Innovation and Its Status in the Malaysian Wood Industry, IFRG Report Singapore 4, 18.

Ratnasingam, J. (2017). The Malaysian Furniture Industry: Unravelling its Growth and Challenges to Innovation, Universiti Putra Malaysia Press, Serdang, Malaysia. ISBN: 978-967-344-412-0

Reinhardt, N. (2000). "Back to basics in Malaysia and Thailand: The role of resourcebased exports in their export-led growth," World Development 28(1), 57-77. DOI: $10.1016 / \mathrm{S} 0305-750 X$ (99)00111-4

Sales, C. (2001). "Technological innovation in the wood sector," Unasylva - An International Journal of Forestry and Forest Industries 52(3), 46-61.

Article submitted: March 7, 2018; Peer review completed: April 22, 2018; Revised version received and accepted; May 17, 2018; Published: May 22, 2018.

DOI: $10.15376 /$ biores.13.3.5254-5270 